\title{
Chemoresistance of Plasmodium falciparum and Plasmodium vivax parasites in Brazil: consequences on disease morbidity and control
}

\author{
Bianca Ervatti Gama', Marcus Vinicius Guimarães Lacerda², \\ Cláudio Tadeu Daniel-Ribeiro1', Maria de Fátima Ferreira-da-Cruz¹/+
}

'Laboratório de Pesquisas em Malária, Centro de Pesquisa, Diagnóstico e Treinamento em Malária, Ministério da Saúde,
Instituto Oswaldo Cruz-Fiocruz, Av. Brasil 4365, 21040-360 Rio de Janeiro, RJ, Brasil
'2Fundação de Medicina Tropical Dr. Heitor Vieira Dourado, Manaus, AM, Brasil

In Brazil, malaria still remains a clinically important febrile syndrome for local populations and travelers, occurring mostly in the Amazon Basin. This review aims to report the main efforts employed to control this disease since the 1940s and the emergence of Plasmodium falciparum and Plasmodium vivax chemoresistance to chloroquine and sulphadoxine-pyrimethamine among other drugs. Additionally, in vivo, in vitro and molecular studies as well as malaria chemoresistance consequences on disease morbidity and policy treatment guidelines were commented.

Key words: Plasmodium falciparum - Plasmodium vivax - malaria - chemoresistance - Brazil

Malaria, one of the most challenging infectious diseases, is an important global public health problem. This disease is endemic in 106 countries and there are reports of about 225 million cases and 781,000 deaths worldwide per year (WHO 2010). In Brazil, despite intensive control efforts, malaria remains clinically important cause of febrile syndrome in local populations and in travellers in areas with endemic transmission, particularly in the Amazon Basin (Oliveira-Ferreira et al. 2010). The Brazilian Amazon comprises nine states: Amazonas (AM), Acre (AC), Roraima (RR), Amapá (AP), Pará (PA), Rondônia (RO), Tocantins (TO), Mato Grosso (MT), and part of Maranhão (MA).

In the 1940s, it was estimated that six million people were infected with malaria per year across Brazil, corresponding to roughly $20 \%$ of the national population. A nationwide campaign for malaria eradication was launched in 1965, as recommended by the World Health Organization (WHO). This campaign, based on indoor dichlorodiphenyltrichloroethane (from its trivial name, DDT) spraying and chloroquine (CQ) treatment for febrile cases, curtailed malaria transmission in the majority of the country (Loiola et al. 2002), and transmission areas were subsequently limited to the north of the country (Fig. 1).

The first report of resistance to an antimalarial drug in Brazil was in 1907. This report was presented anecdotally at a Congress and described the inefficacy of quinine (QN) prophylaxis in workers during the construction of the Madeira-Mamoré Railway in RO. In 1908, Miguel Couto also reported falciparum malaria patients not responding to QN in Rio de Janeiro (RJ), but it was Arthur Neiva (Neiva 1910) who published the first scientific evidence of $\mathrm{QN}$ resistance in workers from $\mathrm{RJ}$ two years later.

+ Corresponding author: mffcruz@ioc.fiocruz.br

Received 23 March 2011

Accepted 1 June 2011
Five decades later, two initial foci of CQ-resistant Plasmodium falciparum parasites were reported in Colombia (Moore \& Lanier 1961, Young \& Moore 1961) and on the frontier between Thailand and Cambodia (Harinasuta et al. 1965). The resistant strains gradually spread throughout Southeast Asia and South America. In Brazil, the first report of CQ-resistant $P$. falciparum cases was in 1961. The famous physician, José Rodrigues da Silva, from Federal University of Rio de Janeiro, identified resistance in individuals returning from road construction in the states of Bahia, RO, PA and MA (Silva 1961), but these findings did not have any repercussion.

Starting in the mid-1960s, the Brazilian government launched and sponsored a massive colonisation project of the northern region in the Amazon Basin. This rapid and uncontrolled migratory movement of non-immune subjects (Daniel-Ribeiro et al. 2008), together with the emergence and expansion of CQ-resistant strains of $P$. falciparum to other Brazilian states such as AC, RR, AM (Ferraroni et al. 1981), MT and AP (Reyes 1981), led to a 10 -fold increase in the incidence of malaria-induced morbidity between 1970 and the mid-1980s. Fortunately, malaria was almost entirely absent from the non-Amazon areas of Brazil at this time.

Expansion of $P$. falciparum $C Q$ chemoresistance, the introduction of sulphadoxine-pyrimethamine (SP) combination and the spread of resistance - Following the appearance of CQ resistance (CQR) in Brazil in the 1960s, other countries in South America and Asia (Clyde 1960, Comer et al. 1968) began reporting the occurrence of CQ-resistant P. falciparum parasites and simultaneously, amodiaquine (AQ)-resistant parasites. This reinforced the call to action for all of the control programs worldwide, as they were now facing the ghost of drug resistance (Souza 1992). The spread of CQ-resistant strains (Box et al. 1963, Silva \& Lopes 1964) accelerated the search for new drugs and SP was highlighted as the new option for falciparum malaria treatment in the 1970s after a clinical trial that showed a high cure rate of CQ-resistant parasites treated with this drug combination (Walker \& Lopez-Antunano 1968). 
Fatefully, the appearance of SP-resistant P. falciparum parasites was verified in Brazilian isolates from TO (Almeida Netto et al. 1972) within a short period of time. Soon after, a high degree of SP-chemoresistance in other states from Brazil was reported (Alecrim et al. 1982a, b, Souza 1983), leading to a climax of at least $90 \% \mathrm{SP}$ resistance (SPR) in 1987 (Souza 1992). By the end of the 1980 s, treatment failure with CQ was increasing, reaching $100 \%$ in some situations (Boulos et al. 1986, Kremsner et al. 1989, Andrade et al. 1992, Couto et al. 1995, Segurado et al. 1997, Póvoa et al. 1998, Zalis et al. 1998, Cerutti et al. 1999b).

Policy treatment changes - By the 1980s, CQ-resistant and SP-resistant $P$. falciparum strains were contributing to the remarkable increase in morbidity (Fig. 2) and, in response to this drug resistance, it was urged that QN should be reintroduced as standard therapy in 1984 in association with tetracycline (Boulos et al. 1986).

In 1986, a new initiative for malaria control and morbidity reduction led to the introduction of other drugs for malarial therapy. This included AQ (Kremsner et al. 1987) and mefloquine (MQ) (Loiola et al. 2002) for the treatment of drug-resistant $P$. falciparum. However, a reduction of the in vivo and in vitro MQ susceptibility (Alecrim 1981) and an in vitro MQ resistance level of $27.5 \%$ had been reported before the official introduction of the drug in 1987 (Boulos et al. 1986). In contrast, some clinical trials (Souza 1983, 1986, Souza et al. 1985) revealed a $100 \%$ cure rate and MQ resistance was not detected by subsequent in vitro studies (Póvoa et al. 1998, Zalis et al. 1998). This contrasted with the previously detected reduction of susceptibility to MQ in vitro (Couto et al. 1995). In 1999, however, Cerutti et al. (1999b) once again recognised the reduction of susceptibility to $M Q$, in addition to observing a case of in vivo resistance (Cerutti et al. 1999a). In the next two years, high levels of MQ resistance were seen in children from AM (Noronha et al. 2000) and in patients from PA (Calvosa et al. 2001).

Concerning $\mathrm{AQ}$, in vivo resistance was also detected at multiple Brazilian localities very soon after its introduction (Reyes et al. 1986, Passos et al. 1987) and high-grade in vitro resistance was rapidly verified (Kremsner et al. 1989).

In 2001, the Brazilian National Malaria Control Program instituted the combination of QN plus doxycycline, followed by primaquine (PQ) as a gametocytocidal drug $(0.75 \mathrm{mg} / \mathrm{kg}$ in a single dose) as a first-line drug combination, and MQ plus PQ was introduced as a secondline drug combination. It is important to remark that $\mathrm{QN}$ was reintroduced as a first-line drug, despite studies in the 1980s that showed the parasites' in vitro chemoresistance to this drug (Souza et al. 1985, Boulos et al. 1986, Souza 1986, Kremsner et al. 1989, Cerutti et al. 1999b, Calvosa et al. 2001). This occurred because WHO had recently recommended the use of drug combinations, instead of single drug therapy, due to the fast ability of $P$. falciparum parasites to develop resistance to individual drugs. QN usage had been instituted in association with tetracycline, a class of antibiotics with slow schizonticidal action, but with a longer half-life than QN. Tetracycline/doxycycline were chosen over clindamycin for association with QN for the following two reasons. First, tetracycline/doxycycline have a lower cost than clindamycin and, second, a large batch of these drugs had been acquired for the treatment of patients with cholera during the outbreak in AM and were therefore available for use (MGC Alecrim, unpublished observations).

As might have been predicted, a continuous increase in QN resistance resulted in a pronounced P. falciparum morbidity intensification, and a phase II study was conducted in the Brazilian Amazon to compare treatments with artemether/lumefantrine $\left(\right.$ Coartem $^{\circledR}$, supplied by Novartis) to QN/doxycycline (Alecrim et al. 2006). In view of the promising results, the artemisinin-combination therapy (ACT) (represented by Coartem) and artesunate plus MQ (supplied by Farmanguinhos) were introduced by the Brazilian Malaria Control Program for uncomplicated falciparum malaria treatment starting in 2007 and 2008, respectively (Ladislau 2008, Carmargo

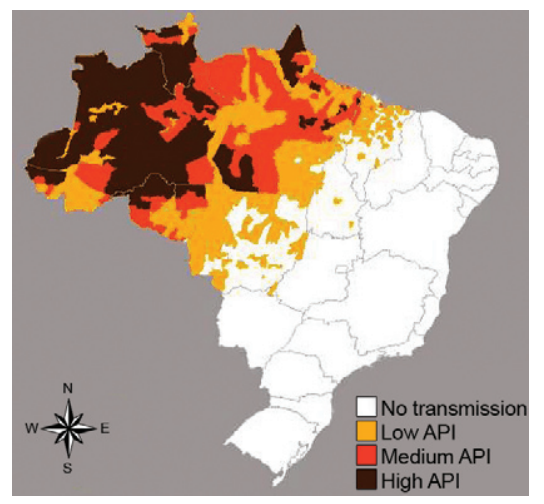

Fig. 1: areas of malaria transmission in Brazil, accordingly to Annual Parasitary Index (API) recorded in 2008. API registers the number of malaria cases $/ 1,000$ inhabitants. Low API indicates that there are less than 10 cases/1,000 inhabitants, medium API indicates 10-49.9 cases/1,000 inhabitants and high API more than 50 cases/1,000 inhabitants.

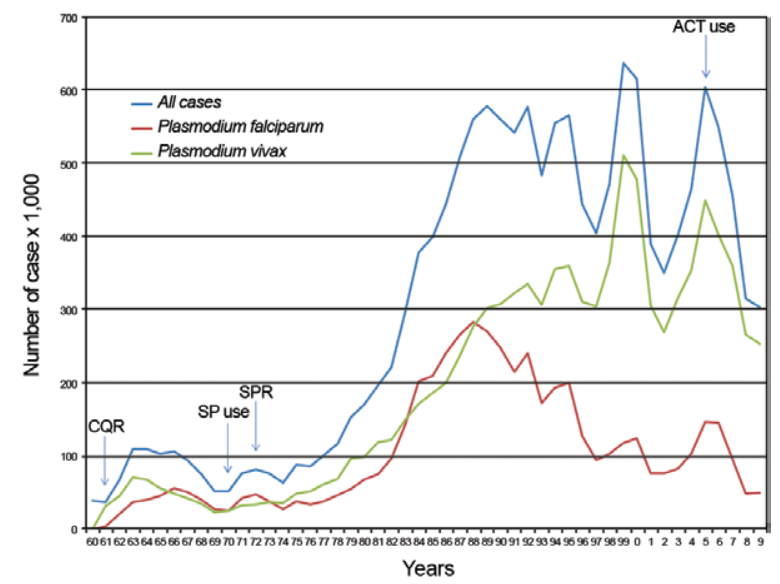

Fig. 2: temporal variation of malaria cases number registered in Brazil from 1960-2009 according to Plasmodium species. Chloroquine resistance (CQR), sulphadoxine-pyrimethamine resistance (SPR) and artemisinin-based combination (ACT) therapy are indicated by arrows. 
et al. 2009). Since the end of the 1990s, parenteral artesunate or artemether had been in use in association with clindamycin for severe malaria treatment.

In adopting ACTs as the first line of treatment for non-severe falciparum malaria, Brazil abolished the systematic use of PQ as a gametocytocidal drug for $P$. falciparum. The only exception involved cases in which gametocytes were observed in the thick blood smear. This decision should be reviewed, because PQ use substantially decreases the carriage of gametocytes (Smithuis et al. 2010), a fact that certainly should have an impact on reducing malaria transmission, and it was demonstrated that PQ is safe to use in glucose-6-phosphate-dehydrogenase (G6PD)-deficient children using the preconised prescript dose (Shekalaghe et al. 2007).

At this time, P. falciparum field isolates from French Guyana and Senegal with reduced in vitro sensitivity to artemether (Jambou et al. 2005), as well as parasites from Cambodia, which exhibit slightly reduced in vitro sensitivity with significant prolongation of parasite clearance times after artesunate therapy have been reported (Noedl et al. 2008, Dondorp et al. 2009). However, no artemisinin derivatives treatment failures have been reported in Brazil. Thus, resistance surveillance, with the support of in vitro studies in sentinel institutions, is essential to predict new policy interventions in the near future.

Emergence of P. vivax chemoresistance - In Brazil, as in many parts of the world, Plasmodium vivax developed resistance to CQ much later than did $P$. falciparum. One possible explanation is that $P$. vivax gametocytes develop much earlier during the course of the disease, when no drug pressure is expected to occur. In the case of $P$. falciparum, gametocytes circulate in the peripheral blood and are accessible to mosquitoes only seven days after disease onset. This not only substantially facilitates parasite control but also results in the selection of gametocytes resistant to the drugs used for therapy.

Studying CQ-resistant $P$. vivax is complicated, even in non-endemic areas due to the possibility of relapses originating from hypnozoites in the liver making it difficult to recognise chemoresistant parasites. In view of this, CQR is acknowledged when there is parasite recurrence in the peripheral blood during the first 28 days after the beginning of CQ therapy, at which time no parasites should be circulating because of the presence of therapeutic drug levels. Ideally, the plasma levels of CQ and its active metabolite, desethylchloroquine, should be dosed to withdraw therapeutic failure and therefore, to institute chemoresistance (Baird 2004, 2009).

In 1992 two Italian authors claimed to have identified the first case of CQR in Brazil (Garavelli \& Corti 1992). Soon after, however, it became clear that it was not a case of a true recrudescence (Loyola \& Rodriguez 1992).

The first reliable case of in vivo CQR in Brazil was from a patient treated at the Tropical Medicine Foundation Dr Heitor Vieira Dourado in Manaus, AM (Alecrim et al. 1999a). These $P$. vivax parasites were also resistant to MQ. Subsequently, the same group also reported a $P$. vivax strain resistant to PQ (a drug used along with CQ for the radical cure of liver stages) and CQ (Alecrim et al. 1999b).
Further evidence of $P$. vivax CQR appeared in 2007, also in Manaus. A proper 28-day follow-up and plasmatic drug dosage was conducted in 109 patients and $10 \%$ of the infections were found to be drug-resistant (Santana Filho et al. 2007). Interestingly, this resistance did not seem to spread throughout the Amazon Region; in a similar study in AC, no CQR was detected (Orjuela-Sánchez et al. 2009a).

It has been claimed that the concomitant use of $\mathrm{PQ}$ and CQ could result in a synergistic effect against asexual forms of $P$. vivax, as has been shown in $P$. falciparum parasites (Bray et al. 2005). However, the few in vivo data available for $P$. vivax show that the parasitological response to CQ and to CQ plus PQ is quite similar (Pukrittayakamee et al. 1994). Consequently, the possibility that such synergism results in the underreporting of CQR in areas where PQ is systematically used should be examined.

It has been hypothesised that severe vivax malaria disease could be related to CQR (Tjitra et al. 2008). Data from Brazil suggest that this relationship would not be straightforward (Alexandre et al. 2010). However, the fact that CQR has increased in many parts of Southeast Asia suggests that CQ should no longer be used routinely. ACTs are the major alternative drugs used to treat $P$. vivax, despite the scarcity of evidence on their efficacy against $P$. vivax parasites (Douglas et al. 2010).

In relation to PQ resistance, it is well-known that the WHO recommended a dose of $0.25 \mathrm{mg} / \mathrm{kg} /$ day for 14 days which differs from the abbreviated regimen of $0.5 \mathrm{mg} / \mathrm{kg} /$ day for seven days (Galappaththy et al. 2007). However, in the mid-1990s, the Brazilian Malaria Control Program changed its policy and recommended the abbreviated regimen due to better compliance and tolerability, despite a slightly inferior efficacy (Krudsood et al. 2008). In spite of the methodological limitation of studying relapses in endemic areas, hypnozoite resistance to PQ is being increasingly reported and in many countries higher doses of PQ are needed for radical cure. It is worth noting that most of these studies had been performed without supervised administration of the drug, which could generate an overestimation of the number of cases of relapses (Baird \& Rieckmann 2003).

In Brazil, one robust study was performed outside the transmission area with supervised treatment of malaria vivax with CQ plus PQ. This study showed a PQ failure rate as high as $24.5 \%$ as determined by relapses, which primarily occurred after three months (Boulos et al. 1991). Another issue that deserves consideration is PQ dosage in patients with G6PD-deficiency. This issue is important because resistance to PQ is dose-dependent and the $\mathrm{A}^{-}$human genotype, the most frequent in Brazil, is associated with severe haemolysis in a dose-dependent manner (Santana et al. 2009, Ramos Junior et al. 2010). In addition, screening for G6PD is not performed routinely before antimalarial treatment in Brazil.

The efficaciously elimination of the hypnozoite is a major concern for malaria control because relapses may contribute enormously to the burden of the disease (Wells et al. 2010). Presently, only PQ is available for the radical cure and very few compounds are under preclinical investigation due to the difficulties of an experimental or in vitro model for large-scale drug screening. 
Tafenoquine is a promising drug with good preliminary data on relapse prevention and with a more convenient posological administration.

Unfortunately, the study of vivax malaria has been relatively neglected until recently. Even in areas where it predominates, local scientific groups concentrate their research on P. falciparum parasites (Lacerda et al. 2007).

P. falciparum and P. vivax surveillance studies Since the Amsterdam Conference at the beginning of the 1990s, early and effective treatment of malaria has been considered the cornerstone of malaria control. Plasmodium resistance to antimalarials is one of the major obstacles to achieving this goal. A systematic, comprehensive and up-to-date monitoring of resistance is important to guide malaria treatment policies, to detect changing patterns early and to avoid the spread of resistance.

Generally, three main approaches are used to study and/or measure antimalarial drug resistance for $P$. falciparum: (i) classical, gold-standard, in vivo follow-up based on clinical and parasitological outcomes obtained in an standard period of time, coupled to complementary analysis to determine the origin of recurrent parasitemia, (ii) an in vitro test based on culturing malaria parasites to measure their intrinsic sensitivity and trends in resistance to antimalarial drugs and, as a modern public health tool, (iii) molecular genotyping of markers to identify genetic mutations that were previously associated with antimalarial drug resistance.

However, for $P$. vivax, the readily obtainable methodologies are elusive. Recognition of resistant parasites is challenging and no consistent, long-term, in vitro method for culturing $P$. vivax parasites is available. Additionally, no trustworthy molecular marker for CQR has been identified thus far.

In Brazil, P. falciparum in vitro tests have been performed since 1981 either alone (Ferraroni et al. 1981, Reyes 1981, Couto et al. 1995, Calvosa et al. 2001, Menezes et al. 2001), in conjunction with in vivo follow-up studies (Boulos et al. 1986, Neifer \& Kremsner 1991, Segurado et al. 1997, Cerutti et al. 1999b) or along with molecular genotyping (Póvoa et al. 1998, Zalis et al. 1998, Vieira et al. 2001, Ferreira et al. 2008).

As far as $P$. falciparum molecular genotyping is concerned, the first informed assay identified only one mutation or single-nucleotide-polymorphism (SNP) in the $p f d h f r$ gene that was associated with pyrimethamine resistance (Peterson et al. 1991). When complete genotyping was performed in Brazil (Vasconcelos et al. 2000), a high number of SNPs were identified in critical codons of the $p f d h f r$ (pyrimethamine) and $p f d h p s$ (sulphadoxine) genes, and these were related to acquisition of full SPR (Cowman et al. 1988, Peterson et al. 1988, Zolg et al. 1989, Brooks et al. 1994). In the case of CQ molecular resistance, two studies published in 1998 presented SNPs of the $p f m d r l$ gene (Póvoa et al. 1998, Zalis et al. 1998), which were associated with a modified response to CQ and to other structurally unrelated antimalarials (Duraisingh \& Cowman 2005). Years later, when resistance to CQ was also ascribed to the gene that encodes a transmembrane transport protein named $p f c r t$ (Fidock et al. 2000), two studies that genotyped the major codons of this gene found that all the isolates presented CQ-resistant haplotypes (Vieira et al. 2001, 2004). This supported the usefulness of this gene as a molecular marker of in vivo CQR.

More recently, a decrease in CQ-sensitive P. falciparum parasites, as well as the downturn of triple mutants associated with SPR, were identified in areas where drug pressure had been removed for a substantial period of time (Kublin et al. 2003, Mita et al. 2003, Wang et al. 2005, Zhou et al. 2008, Bacon et al. 2009). In Brazil, a study examining CQ and SP markers revealed, for the first time in the country, that $P$. falciparum sensitive strains can also circulate in parasite populations, at least in PA (Gama et al. 2009b).

Soon after, in response to the potential development of artemisinin resistance, two studies were published. In the first investigation, the presence of mutations on artemisinin putative resistance-associated genes $p f c r t$, pfmdrl and pfatpase 6 , the absence of a pfatpase 6 chief mutation and satisfactory artemether and artesunate in vitro activities were reported (Ferreira et al. 2008). In the other study, known polymorphisms at $p f m d r l$ and pfatpase6 were identified in samples collected from three Brazilian states before the introduction of ACTs in Brazil. This assembled a genetic snapshot of P. falciparum parasites that could be used as a baseline reference for future studies (Gama et al. 2010).

With respect to $P$. vivax molecular genotyping, orthologous $P$. falciparum genes potentially linked to CQ chemoresistance, such as pvcrt-o and pvmdrl, have been identified (Nomura et al. 2001, Brega et al. 2005). Molecular characterisation of $P$. vivax isolates was also carried out in Brazil (Sá et al. 2005, Gama et al. 2009a, OrjuelaSánchez et al. 2009b). In these publications, the sequence of $p v m d r 1$ in three Brazilian isolates was shown, without association between mutations and in vitro outcomes (Sá et al. 2005). Complete analysis of coding and noncoding sequences of the putative resistance genes pvcrt-o and pvmdrl was conducted in seven samples and no association with CQR was found (Orjuela-Sánchez et al. 2009b). The last survey examined the relationship between SPR and the $p v m d r 1$ and $p v d h f r$ genes in a set of 28 samples (de Pécoulas et al. 1998, Eldin de Pécoulas et al. 1998). This identified a potential leader mutation in $p v m d r l$ in $100 \%$ of the examined isolates (Gama et al. 2009a). This study contrasted with the reported $10 \%$ of in vivo CQ treatment failures (Santana Filho et al. 2007). Moreover, the presence of mutations in $p v d h f r$ gene could reflect the selection of SP-resistant $P$. vivax parasites due to misdiagnosed, or even undiagnosed, P. falciparum and P. vivax co-infections (Gama et al. 2009a).

South-American surveillance network - Amazon Network for the Surveillance of Antimalarial Drug Resistance (RAVREDA) - In 2001, a surveillance network across the Amazon and South American countries was created in response to the challenge of antimalarial drug resistance in the Amazon. It was called RAVREDA and it has received financial support from the US Agency for International Development and the Pan-American Health Organization. 
RAVREDA activities formally began in 2002. Since then, several studies have been performed in Bolivia, Brazil, Colombia, Ecuador, Guyana, French Guiana, Peru, Suriname and Venezuela. The main objectives are to strengthen resistance surveillance and to furnish an evidence-based formulation of drug policies to promote the suitable use of antimalarials.

Evaluation of the therapeutic effectiveness of antimalarials is performed utilising in vivo as well as in vitro efficacy studies. These studies apply a WHO standardised protocol to a sample of patients seeking malaria diagnostic and care services in their own health system. These areas of care services are then identified as sentinel sites. Through 2005, the network has performed 81 studies in South America and has generated information on therapeutic effectiveness that has guided changes in therapeutic regimens in several South American countries (PAHO 2007).

Although the majority of RAVREDA's past activities have concerned $P$. falciparum, one must consider that, in 2004, P. vivax accounted for more than $70 \%$ of all cases of malaria in Latin America (PAHO 2006) and CQ-resistant strains have been reported in Guyana, Peru and Colombia (Soto et al. 2001, Ruebush et al. 2003, Esterre et al. 2009). In Brazil, besides the initial report by Alecrim et al. (1999a) and the report from Santana Filho et al. (2007), another unpublished RAVREDA study performed in the municipality of Careiro (AM), found that $18 \%$ of $P$. vivax infections were CQ-resistant. This was based on determination of the serum levels of both CQ and desethylchloroquine (PAHO 2006).

Brazil is a continental country with approximately 8.5 million square miles and $47 \%$ of South America's landmass. It is responsible for about $56 \%$ of the total malaria cases in the Americas (PAHO 2008). In such a large territory with a huge burden of disease, antimalarial drug surveillance is crucial to maintain an efficient control program.

The data presented herein show that drug resistance surveillance assays must be conducted on a regular basis to assess antimalarial efficacy and to ensure that the information is available to policy makers. At the present time, P. falciparum surveillance studies should investigate artemisinin, as well as its counterparts in ACT formulation; for $P$. vivax, the actual amount of $\mathrm{CQR}$ needs to be determined. Additionally, RAVREDA efforts should be strengthened to allow for easy disclosure of the obtained results.

\section{REFERENCES}

Alecrim M, Alecrim W, Macêdo V 1999a. Plasmodium vivax resistance to chloroquine (R2) and mefloquine (R3) in Brazilian Amazon Region. Rev Soc Bras Med Trop 32: 67-68.

Alecrim M, Alecrim W, Macêdo V, Korves C, Roberts D, Li J, Sullivan M, McCutchan T 1999b. Description of a possible clonal expansion of Plasmodium vivax in Manaus-Amazonas-Brazil. Rev Soc Bras Med Trop 32: 303-305.

Alecrim MG, Alecrim WD, de Albuquerque BC, Dourado HV, Wanssa MoC 1982a. Resistance of Plasmodium falciparum in the Brazilian Amazonas to the combination of sulfadoxine and pyrimethamine. Rev Inst Med Trop Sao Paulo 24: 44-47.
Alecrim MG, Lacerda MV, Mourao MP, Alecrim WD, Padilha A, Cardoso BS, Boulos M 2006. Successful treatment of Plasmodium falciparum malaria with a six-dose regimen of artemetherlumefantrine versus quinine-doxycycline in the western Amazon Region of Brazil. Am J Trop Med Hyg 74: 20-25.

Alecrim MGC 1981. Estudo da resistência do P. falciparum às drogas antimaláricas in vivo $e$ in vitro na Amazônia, MSc Thesis, Universidade de Brasília, Brasília, 116 pp.

Alecrim WD, Dourado H, Alecrim M das G, Passos LF, Wanssa E, Albuquerque B 1982b. In vivo resistance of Plasmodium falciparum to the combination of sulfadoxine and pyrimethamine, at RIII level, in Amazonas, Brazil. Rev Inst Med Trop Sao Paulo 24: 52-53.

Alexandre MA, Ferreira CO, Siqueira AM, Magalhaes BL, Mourao MPG, Lacerda MVG, Alecrim MGC 2010. Severe Plasmodium vivax malaria, Brazilian Amazon. Emerg Infect Dis 16: 1611-1614.

Almeida Netto J, Oliveira G, Sampaio J 1972. Resistência do Plasmodium falciparum à associação sulfamídicos-antifolínicos na Região Centro-Oeste do Brasil; dados referentes ao estudo de 104 casos. Rev Pat Trop 1: 385-393.

Andrade J, Andrade A, Araujo E, Oliveira R, Silva S, Martelli C, Zicker F 1992. A randomized clinical trial with high dose of chloroquine for treatment of Plasmodium falciparum malaria in Brazil. Rev Inst Med Trop Sao Paulo 34: 467-473.

Bacon DJ, McCollum AM, Griffing SM, Salas C, Soberon V, Santolalla M, Haley R, Tsukayama P, Lucas C, Escalante AA, Udhayakumar V 2009. Dynamics of malaria drug resistance patterns in the Amazon Basin Region following changes in Peruvian national treatment policy for uncomplicated malaria. Antimicrob Agents Chemother 53: 2042-2051.

Baird JK 2004. Chloroquine resistance in Plasmodium vivax. Antimicrob Agents Chemother 48: 4075-4083.

Baird JK 2009. Resistance to therapies for infection by Plasmodium vivax. Clin Microbiol Rev 22: 508-534.

Baird JK, Rieckmann KH 2003. Can primaquine therapy for vivax malaria be improved? Trends Parasitol 19: 115-120.

Boulos M, Amato Neto V, Dutra AP, Di Santi SM, Shiroma M 1991. Frequency of malaria relapse due to Plasmodium vivax in a non-endemic region (São Paulo, Brazil). Rev Inst Med Trop Sao Paulo 33: 143-146.

Boulos M, Di Santi SM, Barata LCB, Segurado AAC, Dutra AP, Neves VLF 1986. Some aspects of treatment, prophylaxis and chemoresistance of Plasmodium falciparum malaria. Mem Inst Oswaldo Cruz 81 (Suppl. II): 255-257.

Box ED, Box QT, Young MD 1963. Chloroquine-resistant Plasmodium falciparum from Porto Velho, Brazil. Am J Trop Med Hyg 12: 300-304.

Bray PG, Martin RE, Tilley L, Ward SA, Kirk K, Fidock DA 2005. Defining the role of pfcrt in Plasmodium falciparum chloroquine resistance. Mol Microbiol 56: 323-333.

Brega S, Meslin B, de Monbrison F, Severini C, Gradoni L, Udomsangpetch R, Sutanto I, Peyron F, Picot S 2005. Identification of the Plasmodium vivax mdr-like gene ( $p v m d r l)$ and analysis of single-nucleotide polymorphisms among isolates from different areas of endemicity. J Infect Dis 191: 272-277.

Brooks D, Wang P, Read M, Watkins W, Sims P, Hyde J 1994. Sequence variation of the hydroxymethyldihydropterin pyrophosphokinase: dihydropteroate synthase gene in lines of the human malaria parasite, Plasmodium falciparum, with differing resistance to sulfadoxine. Eur J Biochem 224: 397-405.

Calvosa VS, Adagu IS, Póvoa MM 2001. Plasmodium falciparum: emerging mefloquine resistance in vitro in Para state, North Brazil. Trans R Soc Trop Med Hyg 95: 330-331. 
Carmargo L, de Oliveira S, Basano S, Garcia C 2009. Antimalarials and the fight against malaria in Brazil. Ther Clin Risk Manag 5: 311-317.

Cerutti C, Durlacher RR, de Alencar FE, Segurado AA, Pang LW 1999a. In vivo efficacy of mefloquine for the treatment of falciparum malaria in Brazil. J Infect Dis 180: 2077-2080.

Cerutti C Jr, Marques C, Alencar FEC, Durlacher RR, Alween A, Segurado AAC, Pang LW, Zalis MG 1999b. Antimalarial drug susceptibility testing of Plasmodium falciparum in Brazil using a radioisotope method. Mem Inst Oswaldo Cruz 94: 803-809.

Clyde D 1960. Cross resistance of malaria parasites. Trans $R$ Soc Trop Med Hyg 54: 597-598.

Comer RD, Young MD, Porter JA, Gauld JR, Merritt W 1968. Chloroquine resistance in Plasmodium falciparum malaria on the Pacific coast of Colombia. Am J Trop Med Hyg 17: 795-799.

Couto AA, Calvosa VS, Santos MA, de Souza JM 1995. The evolution over time of the in-vitro resistance of Plasmodium falciparum to antimalarial drugs in 2 areas of the Brazilian Amazonia with distinct socioeconomic and geographic characteristics. Rev Soc Bras Med Trop 28: 357-365.

Cowman A, Morry M, Biggs B, Cross G, Foote S 1988. Amino acid changes linked to pyrimethamine resistance in the dihydrofolate reductase-thymidylate synthase gene of Plasmodium falciparum. Proc Natl Acad Sci USA 85: 9109-9113.

Daniel-Ribeiro C, Lacerda M, Oliveira-Ferreira J 2008. Paludisme dû à Plasmodium vivax en Amazonie brésilienne: quelques aspects de son épidémiologie, de ses manifestations cliniques et des réactions immunitaires naturallement acquises. Bull Soc Pathol Exot 101: 243-248.

de Pécoulas PE, Tahar R, Ouatas T, Mazabraud A, Basco LK 1998. Sequence variations in the Plasmodium vivax dihydrofolate reductase-thymidylate synthase gene and their relationship with pyrimethamine resistance. Mol Biochem Parasitol 92: 265-273.

Dondorp A, Nosten F, Yi P, Das D, Phyo A, Tarning J, Lwin K, Ariey F, Hanpithakpong W, Lee S, Ringwald P, Silamut K, Imwong M, Chotivanich K, Lim P, Herdman T, An S, Yeung S, Singhasivanon P, Day N, Lindegardh N, Socheat D, White N 2009. Artemisinin resistance in Plasmodium falciparum malaria. $N$ Engl J Med 361: 455-467.

Douglas NM, Anstey NM, Angus BJ, Nosten F, Price RN 2010. Artemisinin combination therapy for vivax malaria. Lancet Infect Dis 10: 405-416.

Duraisingh M, Cowman A 2005. Contribution of the pfmdrl gene to antimalarial drug-resistance. Acta Trop 94: 181-190.

Eldin de Pécoulas P, Basco LK, Tahar R, Ouatas T, Mazabraud A 1998. Analysis of the Plasmodium vivax dihydrofolate reductasethymidylate synthase gene sequence. Gene 211: 177-185.

Esterre P, Volney B, Meynard JB, Legrand E 2009. Importance of a regional observatory of malarial chemoresistance, an emerging public health problem in the Guyanas region. Bull Soc Pathol Exot 102: 179-184.

Ferraroni JJ, Speer CA, Hayes J, Suzuki M 1981. Prevalence of chloroquine-resistant falciparum malaria in the Brazilian Amazon. Am J Trop Med Hyg 30: 526-530.

Ferreira I, Martinelli A, Rodrigues L, do Carmo E, do Rosário V, Póvoa M, Cravo P 2008. Plasmodium falciparum from Pará state (Brazil) shows satisfactory in vitro response to artemisinin derivatives and absence of the S769N mutation in the SERCA-type PfATPase6. Trop Med Int Health 13: 199-207.

Fidock DA, Nomura T, Talley AK, Cooper RA, Dzekunov SM, Ferdig MT, Ursos LM, Sidhu AB, Naudé B, Deitsch KW, Su XZ, Wootton JC, Roepe PD, Wellems TE 2000. Mutations in the P. falciparum digestive vacuole transmembrane protein $P f C R T$ and evidence for their role in chloroquine resistance. Mol Cell 6: 861-871.

Galappaththy GN, Omari AA, Tharyan P 2007. Primaquine for preventing relapses in people with Plasmodium vivax malaria. Cochrane Database Syst Ver 1: CD004389.

Gama BE, Almeida de Oliveira NK, Souza JM, Daniel-Ribeiro CT, Ferreira-da-Cruz MF 2009a. Characterisation of pvmdrl and pvdhfr genes associated with chemoresistance in Brazilian Plasmodium vivax isolates. Mem Inst Oswaldo Cruz 104: 1009-1011.

Gama BE, Almeida de Oliveira NK, Zalis MG, Souza JM, Santos F, Daniel-Ribeiro CT, Ferreira-da-Cruz MF 2009b. Chloroquine and sulphadoxine-pyrimethamine sensitivity of Plasmodium falciparum parasites in a Brazilian endemic area. Malaria J 8: 156.

Gama BE, de Oliveira NKA, de Souza JM, Santos F, Carvalho LJM, Melo YFC, Rosenthal PJ, Daniel-Ribeiro CT, Ferreira-da-Cruz MF 2010. Brazilian Plasmodium falciparum isolates: investigation of candidate polymorphisms for artemisinin resistance before introduction of artemisinin-based combination therapy. Malaria J 9: 355.

Garavelli PL, Corti E 1992. Chloroquine resistance in Plasmodium vivax: the first case in Brazil. Trans R Soc Trop Med Hyg 86: 128.

Harinasuta T, Suntharasamai P, Viravan C 1965. Chloroquine-resistant falciparum malaria in Thailand. Lancet 2: 657-660.

Jambou R, Legrand E, Niang M, Khim N, Lim P, Volney B, Ekala M, Bouchier C, Esterre P, Fandeur T, Mercereau-Puijalon O 2005. Resistance of Plasmodium falciparum field isolates to in vitro artemether and point mutations of the SERCA-type PfATPase6. Lancet 366: 1960-1963.

Kremsner PG, Zotter GM, Feldmeier H, Graninger W, Kollaritsch M, Wiedermann G, Rocha RM, Wernsdorfer WH 1989. In vitro drug sensitivity of Plasmodium falciparum in Acre, Brazil. Bull World Health Organ 67: 289-293.

Kremsner PG, Zotter GM, Grainger W, Feldmeier H 1987. Amodiaquine-resistant malaria in Brazil. Lancet 2: 684.

Krudsood S, Tangpukdee N, Wilairatana P, Phophak N, Baird JK, Brittenham GM, Looareesuwan S 2008. High-dose primaquine regimens against relapse of Plasmodium vivax malaria. Am J Trop Med Hyg 78: 736-740.

Kublin JG, Cortese JF, Njunju EM, Mukadam RA, Wirima JJ, Kazembe PN, Djimdé AA, Kouriba B, Taylor TE, Plowe CV 2003. Reemergence of chloroquine-sensitive Plasmodium falciparum malaria after cessation of chloroquine use in Malawi. J Infect Dis 187: 1870-1875.

Lacerda MVG, Zackiewicz C, Alecrim WD, Alecrim MGC 2007. The neglected Plasmodium vivax: are researchers from endemic areas really concerned about new treatment options? Rev Soc Bras Med Trop 40: 489-490.

Ladislau JLB 2008. Status da implementação de ACT no Brasil [homepage on the Internet], Rio de Janeiro. Available from: actwithasmq.org/pdf/Ladislau_MS.pdf.

Loiola C, Mangabeira da Silva C, Tauil P 2002. Controle da malária no Brasil: 1965 a 2001. Rev Panam Salud Publica 11: 235-244.

Loyola EG, Rodriguez MH 1992. Chloroquine-resistant Plasmodium vivax in Brazil. Trans R Soc Trop Med Hyg 86: 570-571.

Menezes C, Kirchgatter K, Di Santi S, Paula G, Ferreira E 2001. In vitro evaluation of quinidine sensitivity in Brazilian Plasmodium falciparum isolates: comparative analysis to quinine and chloroquine. Rev Inst Med Trop Sao Paulo 43: 221-226.

Mita T, Kaneko A, Lum JK, Bwijo B, Takechi M, Zungu IL, Tsukahara T, Tanabe K, Kobayakawa T, Björkman A 2003. Recovery of chloroquine sensitivity and low prevalence of the Plasmodium 
falciparum chloroquine resistance transporter gene mutation K76 $\mathrm{T}$ following the discontinuance of chloroquine use in Malawi. Am J Trop Med Hyg 68: 413-415.

Moore D, Lanier J 1961. Observations on two Plasmodium falciparum infections with an abnormal response to chloroquine. Am J Trop Med Hyg 10: 5-9.

Neifer S, Kremsner PG 1991. Drug susceptibility of Plasmodium falciparum in the western Amazon Region, state of Acre, Brazil. Rev Inst Med Trop Sao Paulo 33: 205-211.

Neiva A 1910. Formação de raça do hematozoário do impaludismo rezistente à quinina. Mem Inst Oswaldo Cruz 2: 131-140.

Noedl H, Se Y, Schaecher K, Smith B, Socheat D, Fukuda M 2008. Evidence of artemisinin-resistant malaria in western Cambodia. N Engl J Med 359: 2619-2620.

Nomura T, Carlton JM, Baird JK, del Portillo HA, Fryauff DJ, Rathore D, Fidock DA, Su X, Collins WE, McCutchan TF, Wootton JC, Wellems TE 2001. Evidence for different mechanisms of chloroquine resistance in 2 Plasmodium species that cause human malaria. J Infect Dis 183: 1653-1661.

Noronha E, Alecrim MG, Romero GA, Macêdo V 2000. RIII mefloquine resistance in children with falciparum malaria in Manaus, AM, Brazil. Rev Soc Bras Med Trop 33: 201-205.

Oliveira-Ferreira J, Lacerda MV, Brasil P, Ladislau JL, Tauil PL, DanielRibeiro CT 2010. Malaria in Brazil: an overview. Malaria J 9: 115.

Orjuela-Sánchez P, da Silva NS, da Silva-Nunes M, Ferreira MU 2009a. Recurrent parasitemias and population dynamics of Plasmodium vivax polymorphisms in rural Amazonia. Am J Trop Med Hyg 81: 961-968.

Orjuela-Sánchez P, de Santana Filho FS, Machado-Lima A, Chehuan YF, Costa MR, Alecrim MG, del Portillo HA 2009b. Analysis of singlenucleotide polymorphisms in the crt-o and $\mathrm{mdrl}$ genes of Plasmodium vivax among chloroquine-resistant isolates from the Brazilian Amazon Region. Antimicrob Agents Chemother 53: 3561-3564.

PAHO - Pan American Health Organization 2006. RAVREDA: workshop on Measuring Antimalarial Serum Levels [homepage on the Internet], Belém. Available from: paho.org/English/AD/DPC/ $\mathrm{CD} /$ ravreda-ami-areas.htm.

PAHO - Pan American Health Organization 2007. RAVREDA-AMI: Amazon Network for the Surveillance of Antimalarial Drug Resistance/Amazon Malaria Initiative [homepage on the Internet]. Available from: paho.org/English/AD/DPC/CD/ravreda-ami.htm.

PAHO - Pan American Health Organization 2008. Report on situation of malaria in the Americas. Regional chapter. [homepage on the Internet]. Available from: new.paho.org/hq/index. php?option=com_content\&task=view\&id=2459\&Itemid=2000.

Passos AD, Osanai CH, Reyes S 1987. In vivo resistance of Plasmodium falciparum to 4-aminoquinolines and to a sulfadoxine-pyrimethamine combination. II - The Emperatriz study, Maranhão, 1983-1984. Rev Soc Bras Med Trop 20: 109-113.

Peterson DS, Di Santi SM, Povoa M, Calvosa VS, Do Rosario VE, Wellems TE 1991. Prevalence of the dihydrofolate reductase Asn-108 mutation as the basis for pyrimethamine-resistant falciparum malaria in the Brazilian Amazon. Am J Trop Med Hyg 45: 492-497.

Peterson DS, Walliker D, Wellems TE 1988. Evidence that a point mutation in dihydrofolate reductase-thymidylate synthase confers resistance to pyrimethamine in falciparum malaria. Proc Natl Acad Sci USA 85: 9114-9118.

Póvoa M, Adagu I, Oliveira S, Machado R, Miles M, Warhurst D 1998. Pfmdr1 Asn1042Asp and Asp1246Tyr polymorphisms, thought to be associated with chloroquine resistance, are present in chloroquine-resistant and sensitive Brazilian field isolates of Plasmodium falciparum. Exp Parasitol 88: 64-68.
Pukrittayakamee S, Vanijanonta S, Chantra A, Clemens R, White NJ 1994. Blood stage antimalarial efficacy of primaquine in Plasmodium vivax malaria. J Infect Dis 169: 932-935.

Ramos Junior WM, Sardinha JF, Costa MR, Santana MS, Alecrim MG, Lacerda MV 2010. Clinical aspects of hemolysis in patients with $P$. vivax malaria treated with primaquine, in the Brazilian Amazon. Braz J Infect Dis 14: 410-412.

Reyes S 1981. Malarial infections caused by Plasmodium falciparum resistant to chloroquine treatment. The situation in Brazil (19601981). Rev Bras Malariol Doencas Trop 33: 109-130.

Reyes S, Osanai CH, Passos AD 1986. In vivo resistance of Plasmodium falciparum to 4-aminoquinolines and to a sulfadoxine-pyrimethamine combination. II. Study of Manaus, Amazonas 19831984. Rev Bras Malariol Doencas Trop 38: 37-44.

Ruebush TK, Zegarra J, Cairo J, Andersen EM, Green M, Pillai DR, Marquiño W, Huilca M, Arévalo E, Garcia C, Solary L, Kain KC 2003. Chloroquine-resistant Plasmodium vivax malaria in Peru. Am J Trop Med Hyg 69: 548-552.

Sá JM, Nomura T, Neves J, Baird JK, Wellems TE, del Portillo HA 2005. Plasmodium vivax: allele variants of the $m d r l$ gene do not associate with chloroquine resistance among isolates from Brazil, Papua, and monkey-adapted strains. Exp Parasitol 109: 256-259.

Santana Filho F, Arcanjo A, Cheuan Y, Costa M, Martinez-Espinosa F, Vieira J, Barbosa M, Alecrim W, MG A 2007. Chloroquineresistant Plasmodium vivax, Brazilian Amazon. Emerg Infect Dis 13: 1125-1126.

Santana MS, Lacerda MVG, Barbosa MGV, Alecrim WD, Alecrim MGC 2009. Glucose-6-phosphate dehydrogenase deficiency in an endemic area for malaria in Manaus: a cross-sectional survey in the Brazilian Amazon. PLoS ONE 4: e5259.

Segurado AA, di Santi SM, Shiroma M 1997. In vivo and in vitro Plasmodium falciparum resistance to chloroquine, amodiaquine and quinine in the Brazilian Amazon. Rev Inst Med Trop Sao Paulo 39: 85-90.

Shekalaghe S, Drakeley C, Gosling R, Ndaro A, van Meegeren M, Enevold A, Alifrangis M, Mosha F, Sauerwein R, Bousema T 2007. Primaquine clears submicroscopic Plasmodium falciparum gametocytes that persist after treatment with sulphadoxine-pyrimethamine and artesunate. PLOS ONE 2: e1023.

Silva J 1961. Terçã maligna cloroquino-resistente - uma séria ameaça ao Hinterland brasileiro. Tribuna Medica 160: 2-6.

Silva JR, Lopes PF 1964. Chloroquine resistance in Plasmodium falciparum in Brazil. Rev Bras Malariol Doencas Trop 16: 301-310.

Smithuis F, Kyaw MK, Phe O, Win T, Aung PP, Oo AP, Naing AL, Nyo MY, Myint NZ, Imwong M, Ashley E, Lee SJ, White NJ 2010. Effectiveness of five artemisinin combination regimens with or without primaquine in uncomplicated falciparum malaria: an open-label randomised trial. Lancet Infect Dis 10: 673-681.

Soto J, Toledo J, Gutierrez P, Luzz M, Llinas N, Cedeño N, Dunne M, Berman J 2001. Plasmodium vivax clinically resistant to chloroquine in Colombia. Am J Trop Med Hyg 65: 90-93.

Souza JM 1983. A phase II clinical trial of mefloquine in Brazilian male subjects. Bull World Health Organ 61: 815-820.

Souza JM 1986. Mefloquine clinical trials - therapeutical experience with mefloquine alone and combination (MSP) in Brazilian male subjects with falciparum malaria. Mem Inst Oswaldo Cruz 81 (Suppl. II): 259-268.

Souza JM 1992. Epidemiological distribution of Plasmodium falciparum drug resistance in Brazil and its relevance to the treatment and control of malaria. Mem Inst Oswaldo Cruz 87 (Suppl. III): 343-348.

Souza JM, Sheth UK, de Oliveira RM, Roulet H, de Souza SD 1985. An open, randomized, phase III clinical trial of mefloquine and 
of quinine plus sulfadoxine-pyrimethamine in the treatment of symptomatic falciparum malaria in Brazil. Bull World Health Organ 63: 603-609.

Tjitra E, Anstey NM, Sugiarto P, Warikar N, Kenangalem E, Karyana M, Lampah DA, Price RN 2008. Multidrug-resistant Plasmodium vivax associated with severe and fatal malaria: a prospective study in Papua, Indonesia. PLoS Medicine 5: e128.

Vasconcelos KF, Plowe CV, Fontes CJ, Kyle D, Wirth DF, Pereira da Silva LH, Zalis MG 2000. Mutations in Plasmodium falciparum dihydrofolate reductase and dihydropteroate synthase of isolates from the Amazon Region of Brazil. Mem Inst Oswaldo Cruz 95: 721-728.

Vieira PP, das Graças Alecrim M, da Silva LH, González-Jiménez I, Zalis MG 2001. Analysis of the PfCRT K76T mutation in Plasmodium falciparum isolates from the Amazon Region of Brazil. J Infect Dis 183: 1832-1833.

Vieira PP, Ferreira MU, Alecrim MG, Alecrim WD, da Silva LH, Sihuincha MM, Joy DA, Mu J, Su XZ, Zalis MG 2004. pfcrt polymorphism and the spread of chloroquine resistance in Plasmodium falciparum populations across the Amazon Basin. J Infect Dis 190: 417-424.

Walker A, Lopez-Antunano F 1968. Response to drugs of South American strains of Plasmodium falciparum. Trans $R$ Soc Trop Med Hyg 62: 654-667.

Wang X, Mu J, Li G, Chen P, Guo X, Fu L, Chen L, Su X, Wellems TE 2005. Decreased prevalence of the Plasmodium falciparum chlo- roquine resistance transporter $76 \mathrm{~T}$ marker associated with cessation of chloroquine use against $P$. falciparum malaria in Hainan, People's Republic of China. Am J Trop Med Hyg 72: 410-414.

Wells TN, Burrows JN, Baird JK 2010. Targeting the hypnozoite reservoir of Plasmodium vivax: the hidden obstacle to malaria elimination. Trends Parasitol 26: 145-151.

WHO - World Health Organization 2010. World Malaria Report 2010 [homepage on the internet]. Available from: who.int/malaria/ world_malaria_report_2010/en/index.html.

Young M, Moore D 1961. Chloroquine resistance in Plasmodium falciparum. Am J Trop Med Hyg 10: 317-320.

Zalis M, Pang L, Silveira M, Milhous W, Wirth D 1998. Characterization of Plasmodium falciparum isolated from the Amazon Region of Brazil: evidence for quinine resistance. Am J Trop Med Hyg 58: 630-637.

Zhou Z, Griffing SM, de Oliveira AM, McCollum AM, Quezada WM, Arrospide N, Escalante AA, Udhayakumar V 2008. Decline in sulfadoxine-pyrimethamine-resistant alleles after change in drug policy in the Amazon region of Peru. Antimicrob Agents Chemother 52: 739-741.

Zolg JW, Plitt JR, Chen GX, Palmer S 1989. Point mutations in the dihydrofolate reductase-thymidylate synthase gene as the molecular basis for pyrimethamine resistance in Plasmodium falciparum. Mol Biochem Parasitol 36: 253-262. 